С. О.Дичко ${ }^{1}$, В. І.Назаренко ${ }^{2}$

${ }^{1}$ Східне регіональне управління Держприкордонслужби України, Харків, Україна

${ }^{2}$ Головний центр підготовки особового складу Держприкордонслужби України, Черкаси, Україна

\title{
ВИКОРИСТАННЯ МАТЕМАТИЧНОГО АПАРАТУ ДОСЛІДЖЕННЯ ОПЕРАЦІЙ ДЛЯ ВИЗНАЧЕННЯ ОПТИМАЛЬНОЇ СТРУКТУРИ СИЛ ДЛЯ ЛІКВЦДАЦЇ̈ НАСЛІДКІВ НАДЗВИЧАЙНОЇ СИТУАЦЇ̈ У ЗАГОНІ ДЕРЖПРИКОРДОНСЛУЖБИ УКРАЇНИ
}

Анотація. Предметом вивчення в статті є процес ліквідації наслідків надзвичайної ситуації у прикордонному загоні Державної прикордонної служби України. Метою дослідження $є$ розробка математичної моделі складу сил та засобів обробки служби радіаційного, хімічного та біологічного захисту та екологічної безпеки загону Держприкордонслужби України. Завдання: зробити математичне формулювання задачі визначення складу зведеного підрозділу служби радіаційного, хімічного та біологічного захисту та екологічної безпеки Держприкордонслужби України за критерієм максимуму ефективності дій його розрахункових одиниць у надзвичайній ситуації; запропонувати розв'язання отриманої задачі шляхом зведення її до задачі математичного програмування; на основі отриманого розрахунку визначити структуру та процедуру всебічного забезпечення сил та засобів обробки служби радіаційного, хімічного та біологічного захисту та екологічної безпеки Держприкордонслужби України. Методологічною основою дослідження стали загальнонаукові та спеціальні методи наукового пізнання. Отримані такі результати: завдання визначення оптимального складу зведеного підрозділу служби радіаційного, хімічного та біологічного захисту та екологічної безпеки Держприкордонслужби України сформульована як задача нелінійного цілочисленого програмування. Цільова функція ефективності дій розрахункових одиниць зведеного підрозділу при ліквідації наслідків надзвичайної ситуації у прикордонному загоні розглянута як сепарабельна та замінена на відповідну лінеаризовану. Висновки. Завдання визначення оптимального складу сил та засобів обробки служби радіаційного, хімічного та біологічного захисту та екологічної безпеки Держприкордонслужби України може бути зведена до класичної розподільчої задачі лінійного програмування транспортного типу. Для організації всебічного забезпечення дій розрахункових одиниць необхідно виконати умову укомплектування та оснащення підрозділів, яка відповідає закритій розподільчій задачі лінійного програмування транспортного типу.

Ключов і слов а : ліквідація наслідків надзвичайної ситуації, математичне програмування, складу сил та засобів обробки служби радіаційного, хімічного та біологічного захисту та екологічної безпеки загону Держприкордонслужби України.

\section{Вступ}

Постановка проблеми та завдання дослідження. За останні десятиріччя в Україні спостерігається негативна тенденція зростання кількості надзвичайних ситуацій природного й техногенного характеру, які почали призводити в деяких районах до незворотних змін навколишнього природного середовища й позначатися на загальному стані економіки та безпеки держави.

Для ефективного виконання завдань щодо ліквідації наслідків надзвичайних ситуацій залучаються сили та засоби обробки служби радіаційного, хімічного та біологічного захисту (РХБЗ) та екологічної безпеки Держприкордонслужби України (ДПСУ). Дані обставини вимагають нового підходу до організації і здійснення захисту особового складу ДПСУ та населення щодо якісного вдосконалення єдиної Державної системи запобігання та реагування на надзвичайні ситуації техногенного та природного характеру. У зв'язку з цим виникає необхідність вирішення задачі оптимізації як структури підрозділу прикордонного загону так і організації його всебічного забезпечення.

Аналіз останніх досліджень і публікацій засвідчує, що наявність небезпечних об'єктів на території військових частин та можливих масштабів i наслідків надзвичайних ситуацій під час аварії на них, або їх зруйнування, вимагає організованого ведення рятувальних і інших невідкладних робіт, завчасно має бути створений зведений підрозділ, який має потрібні сили та засоби, структуру, оптимальну до надзвичайної ситуації структуру та процедуру всебічного забезпечення [1-3]. Зрозуміло, що це буде зовсім не організаційно-штатна структура, яка $\epsilon$ незмінною й тому слабо пристосованою до конкретної специфічної ситуації.

Метою статті $є$ розробка математичної моделі визначення оптимального складу сил та засобів обробки служби РХБЗ та екологічної безпеки ДПСУ.

Для досягнення поставленої мети визначені завдання дослідження:

- зробити математичне формулювання задачі визначення складу зведеного підрозділу служби РХБЗ та екологічної безпеки ДПСУ за критерієм максимуму ефективності дій його розрахункових одиниць у надзвичайної ситуації;

- запропонувати розв'язання отриманої задачі шляхом зведення іiі до задачі математичного програмування;

- на основі отриманого розрахунку визначити структуру та процедуру всебічного забезпечення сил та засобів обробки служби РХБЗ та екологічної безпеки ДПСУ.

\section{Виклад основного матеріалу}

1. Зміст задачі визначення складу зведеного підрозділу служби РХБЗ та екологічної безпеки 
ДПСУ за критерієм максимуму ефективності дій його розрахункових одиниць у надзвичайної ситуації. Припустимо, що застосування сил та засобів обробки служби РХБЗ та екологічної безпеки Держприкордонслужби України при ліквідації наслідків будь-якої надзвичайної ситуації полягає у виконанні $n$ різнорідних завдань щодо досягнення загальної мети.

Для виконання цих завдань будуть задіяні $m$ типів різнорідних за спеціалізаціями підрозділів військової частини.

Сили і засоби кожного підрозділу організовані у розрахункові одиниці (р.о.) за $m$ типами спеціалізацій, що складають вектор $R$

$$
R=\left\langle r_{i}\right\rangle, i=\overline{1, m},
$$

та будуть розподілені таким чином, що для кожного $j$-го завдання (заходу) рятувальних та інших невідкладних робіт залучатимуться $x_{\mathrm{ij}}$ розрахункових одиниць (р.о.) $i$-го типу, $i=\overline{1, m}, j=\overline{1, n}$.

Таким чином, планом розподілу сил і засобів по завданнях є матриця:

$$
X=\left[x_{i j}\right], i=\overline{1, m}, j=\overline{1, n},
$$

де $x_{i j}$ - кількість р. о. $i$-го типу, що призначаються на $j$-те завдання.

За умови здорового глузду приймаємо обмеження на значення $x_{i j}, i=\overline{1, m}, j=\overline{1, n}$ :

$$
\begin{aligned}
& x_{i j} \geq 0 ; \\
& x_{i j} \in Z .
\end{aligned}
$$

Припустимо, що ефективність дії кожної р.о. при виконанні ним завдань має сенс ймовірності.

Числові значення цієї ефективності $0 \leq p_{i j} \leq 1$, $i=\overline{1, m}, j=\overline{1, n}$, утворюють матрицю $P$ :

$$
P=\left[p_{i j}\right], i=\overline{1, m}, j=\overline{1, n},
$$

де $p_{i j}$ - ефективність дій р.о. $i$-го типу, що призначається для виконання $j$-го завдання.

Приймаємо, що особовий склад кожної р.о. має одинаковий рівень підготовки та забезпечення матеріально-технічними засобами, і ефективність дій при виконанні одного завдання не впливає на ефективність виконання інших завдань. Тоді за класичною теоремою повторення дослідів виконання $j$-го завдання становитиме [4]

$$
p_{j}=1-\prod_{i=1}^{m}\left(1-p_{i j}\right)^{x_{i j}} \text {. }
$$

Завдання, що виконуються $з$ метою ліквідації наслідків надзвичайної ситуації є різними за пріоритетом виконання. Поставимо кожному -му завданню деяке число $c_{j}>0$, яке буде відповідати його пріоритету.

$$
C=\left\langle c_{j}\right\rangle, j=\overline{1, n} \text {. }
$$

Значення цієї величини можуть бути отримані, наприклад, шляхом експертного оцінювання. Природно вважати, що найважливіше завдання матиме найменше значення $c_{j}$, тому для знаходження цільової функції, із сенсом знаходження максимального значення будемо використовувати обернену величину, $b_{j}=1 / c_{j}, j=\overline{1, n}$.

3 врахування виразів (6) та (7), ефективність дій сил і засобів $x_{i j}-\ddot{i}$ кількості при виконанні $j$-го завдання складатиме

$$
\begin{gathered}
W_{j}=\frac{1}{c_{j}} \cdot\left(1-\prod_{i=1}^{m}\left(1-p_{i j}\right)^{x_{i j}}\right)= \\
=b_{j} \cdot\left(1-\prod_{i=1}^{m}\left(1-p_{i j}\right)^{x_{i j}}\right) . \\
b_{j}=1 / c_{j}, j=\overline{1, n} ; \\
i=\overline{1, m} .
\end{gathered}
$$

Сумарна ефективність щодо виконання усіх $n$ завдань складатиме

$$
\begin{gathered}
Z\left(x_{i j}\right)=\sum_{j=1}^{n} W_{j}=\sum_{j=1}^{n} \frac{1}{c_{j}}\left(1-\prod_{i=1}^{m}\left(1-p_{i j}\right)^{x_{i j}}\right) \\
i=\overline{1, m} \\
j=\overline{1, n}
\end{gathered}
$$

Природно вважати, що сумарний склад р.о. кожного типу, який планується розподілити по видах завдань, не повинний перевищувати його загальну кількість.

$$
\sum_{j=1}^{n} x_{i j} \leq r_{i}, j=\overline{1, n}
$$

Задача визначення оптимального складу зведеного підрозділу служби РХБЗ та екологічної безпеки ДПСУ за критерієм максимуму ефективності дій його розрахункових одиниць у надзвичайної ситуації може бути сформульована таким чином:

Знайти план $X^{*}=\left[x_{i j}^{*}\right], i=\overline{1, m}, j=\overline{1, n}$, такий що максимізує функціонал

$$
Z\left(x_{i j}\right)=\sum_{j=1}^{n} \frac{1}{c_{j}}\left(1-\prod_{i=1}^{m}\left(1-p_{i j}\right)^{x_{i j}}\right)
$$

та задовольняє обмеженням:

$$
\sum_{j=1}^{n} x_{i j} \leq r_{i}
$$




$$
\begin{aligned}
& x_{i j} \geq 0 \\
& x_{i j} \in Z \\
& i=\overline{1, m} \\
& j=\overline{1, n}
\end{aligned}
$$

Задача (13)-(20) може бути віднесена до задачі нелінійного цілочисленого програмування.

2. Зведення задачі визначення оптимального складу зведеного підрозділу служби РХБЗ та екологічної безпеки ДПСУ до задачі математичного програмування. 3 огляду на вираз (11) цільова функція ефективності дій р.о. служби РХБЗ та екологічної безпеки ДПСУ може бути розглянута як сепарабельна (роздільна), оскільки може бути подана у вигляді суми $n$ функцій однієї змінної $x$.

$$
\begin{gathered}
Z\left(x_{i j}\right)=\sum_{j=1}^{n} W_{j}=\sum_{j=1}^{n} \frac{1}{c_{j}}\left(1-\prod_{i=1}^{m}\left(1-p_{i j}\right)^{x_{i j}}\right)= \\
=\sum_{j=1}^{n} b_{j}-\sum_{j=1}^{n} \frac{1}{c_{j}}\left(1-\prod_{i=1}^{m}\left(1-p_{i j}\right)^{x_{i j}}\right) \Rightarrow \max .
\end{gathered}
$$

Оскільки величина $\sum_{j=1}^{n} b_{j} \epsilon$ фіксованою, пропонується цільову функцію знаходити так:

$$
Z^{\prime}\left(x_{i j}\right)=\sum_{j=1}^{n} \frac{1}{c_{j}}\left(1-\prod_{i=1}^{m}\left(1-p_{i j}\right)^{x_{i j}}\right) \Rightarrow \min .
$$

Тобто, сепарабельна задача, еквівалента до задачі (13)-(20), може бути сформульована наступним чином:

Знайти набір $X^{\prime^{*}}=\left[x_{i j}^{*}\right], i=\overline{1, m}, j=\overline{1, n}$, такий що мінімізує функціонал

$$
Z^{\prime \prime}\left(x_{i j}\right)=\sum_{j=1}^{n} \frac{1}{c_{j}} F_{j}\left(x_{j}\right) \Rightarrow \min
$$

та задовольняє обмеженням

$$
\begin{gathered}
\sum_{j=1}^{n} x_{i j} \leq r_{i} ; \\
x_{i j}^{\prime \prime} \geq 0 ; \\
x_{i j} \in Z, \\
F_{j}=\sum_{j=1}^{n} \frac{1}{c_{j}} \prod_{i=1}^{m}\left(1-p_{i j}\right)^{x_{i j} ;} ; \\
i=\overline{1, m} ;
\end{gathered}
$$

$$
j=\overline{1, n} .
$$

3 огляду на $[5,6]$ пропонується застосування методів наближеного розв'язання задачі сепарабельного програмування, що засновані на лінійній апроксимації функцій і на симплекс-методі лінійного програмування. функцію однієї змінної можна апроксимувати кусочно-лінійною функцією за допомогою методів частково-цілочисельного програмування.

Так, задача (23)-(29) може бути вирішена методами частково-цілочисельного програмування. Для вирішення апроксимуючої завдання можна використовувати звичайний симплекс-метод, доповнений правилом обмеженого введення в базис.

Для лінеаризації доданків цільової функції (23) про логарифмуємо вираз (27). Виходячи з того, що значення ефективності дій р.о. має сенс ймовірності, тобто $0 \leq p_{i j} \leq 1, i=\overline{1, m}, j=\overline{1, n}$, а відповідно, значення $0 \leq 1-p_{i j} \leq 1$, цільова функція буде мати вигляд

$$
\begin{gathered}
\widehat{Z}\left(x_{i j}\right)=\ln \sum_{j=1}^{n} \frac{1}{c_{j}} F_{j}\left(x_{j}\right)=\sum_{j=1}^{n} \ln \prod_{i=1}^{m}\left(1-p_{i j}\right)^{x_{i j}}= \\
=\sum_{j=1}^{n} \ln \prod_{i=1}^{m}\left(1-p_{i j}\right)^{x_{i j}}=\sum_{j=1}^{n} \sum_{i=1}^{m} \frac{\ln \left(1-p_{i j}\right)}{c_{j}} x_{i j} \Rightarrow \max . \text { (30) } \\
\text { При введенні позначення } \quad d_{i j}=\frac{\ln \left(1-p_{i j}\right)}{c_{j}},
\end{gathered}
$$
цільова функція (30) прийме вигляд

$$
\widehat{Z}\left(x_{i j}\right)=\sum_{i=1}^{m} \sum_{j=1}^{n} d_{i j} x_{i j} \Rightarrow \max ,
$$

Таким чином, задача визначення оптимального складу сил та засобів обробки служби РХБЗ та екологічної безпеки ДПСУ може бути зведена до класичної розподільчої задачі лінійного програмування транспортного типу.

3. Визначення структури та процедуру всебічного забезпечення сил та засобів обробки служби РХБЗ та екологічної безпеки ДПСУ. Припустимо, що шляхом розв'язання задачі (31), (24)(29) отримана матриця

$$
\widehat{X}^{*}=\left[\hat{x}^{*}{ }_{i j}\right], i=\overline{1, m}, j=\overline{1, n}
$$

значення елементів якої відповідають р.о. $i$-го типу, що залучатимуться для кожного $j$-го завдання (заходу) рятувальних та інших невідкладних робіт.

Виходячи 3 цього, матриця (32) визначає оптимальний сил та засобів обробки служби РХБЗ та екологічної безпеки ДПСУ по завданнях при ліквідації наслідків будь-якої надзвичайної ситуації.

У цьому випадку для ефективного виконання $j$-го завдання будуть залучені такі сили і засоби: 


$$
X_{j}^{*}=\sum_{i=1}^{m} \hat{x}_{i j}^{*}, i=\overline{1, m},
$$

Оптимальне укомплектування та оснащення підрозділів за кожною $3 m$ спеціалізацій буде визначатися виразом:

$$
\sum_{j=1}^{n} \hat{x}_{i j}^{*} \leq s_{i}^{*}
$$

де $s_{i}, i=\overline{1, m},-$ сили та засобів обробки служби РХБЗ та екологічної безпеки ДПСУ для вирішення кожного $j$-го завдання (заходу) рятувальних та інших невідкладних робіт.

Для організації всебічного забезпечення дій p.o. необхідно виконати умову укомплектування та оснащення підрозділів

$$
\sum_{i=1}^{m} s_{i}=\sum_{j=1}^{n} r_{j}
$$

При виконанні умови (35) задача (31), (24)-(29) буде класифікуватися як закрита, в противному випадку, як відкрита. Механізм приведення відкритої транспортної задачі до закритої відомі [7], але невиконання умови (35) буде свідчити про брак сил та засобів сили та засобів обробки служби РХБЗ та екологічної безпеки Держприкордонслужби України та вимагатиме організаційних заходів щодо його усунення.

\section{Висновки}

1. Задача визначення оптимального складу сил та засобів обробки служби РХБЗ та екологічної безпеки ДПСУ може бути зведена до класичної розподільчої задачі лінійного програмування транспортного типу.

2. Для організації всебічного забезпечення дій p.o. необхідно виконати умову укомплектування та оснащення підрозділів, яка відповідає закритій розподільчій задачі лінійного програмування транспортного типу.

\section{СПИСОК ЛІТЕРАТУРИ}

1. Коробка В.П., Гаврилко С.В. Підрозділи Державної прикордонної служби України в єдиній державній системі цивільного захисту населення й територій / Наука і оборона. - 2011. - №3. - С.17-21.

2. Хіврич О.В., Литвиненко А.М. Деякі погляди щодо визначення критерію ефективності оптимальної структури сил об'єктових формувань цивільної оборони. / Наукові праці НУХТ -2007. - № 20. - С.69-72.

3. Хіврич О.В. Вибір показників і критерію ефективності функціонування системи управління цивільним захистом населення і території при ліквідації наслідків надзвичайних ситуацій / О. В. Хіврич, Н. В. Володченкова, А.М. Литвиненко // Харчова промисловість. - 2014. - № 15. - С. 155-159.

4. Вентцель Е.С. Теория вероятностей / Е. С. Вентцель. - М.: Наука, Физматгиз, $1969-576$ с.

5. Акулич И.Л. Математическое программирование в примерах и задачах: Учебное пособие для студентов экономических специальностей. -М.: Высш. шк., 1986. -319 с.

6. Хемди А. Таха. Введение в исследование операций. - М: Издательский дом «Вильямс», 2005. -912 с.

7. Вентцель Е. С. Исследование операций / Е. С. Вентцель - М.: Советское радио, 1972. - 552c.

\section{Use of mathematical apparatus of study of operations to determine the optimal structure of forces for liquidation of consequences of legacy}

Serhii Dychko, Vitaliy Nazarenko

Abstract. The subject matter of the article is a process of liquidation of the consequences of the emergency situation in the border detachment of the State Border Guard Service of Ukraine. The goal of the study is the development of a mathematical model of the composition of forces and means of processing the service of radiation, chemical and biological protection and environmental safety of the State Border Guard Service of Ukraine. The tasks to be solved are: to make a mathematical formulation of the problem of determining the composition of the consolidated unit of the service of radiation, chemical and biological protection and environmental safety of the State Border Guard Service of Ukraine by the criterion of maximum efficiency of its units in an emergency situation; to propose the solution of the obtained problem by reducing it to the problem of mathematical programming; on the basis of the received calculation to determine the structure and procedure of comprehensive provision of forces and means of processing of the service of radiation, chemical and biological protection and ecological safety of the State Border Guard Service of Ukraine. General scientific and special methods of scientific knowledge are used. The following results are obtained. The problem of determining the optimal composition of the consolidated unit of the service of radiation, chemical and biological protection and environmental safety of the State Border Guard Service of Ukraine is formulated as a problem of nonlinear integer programming. The objective function of the effectiveness of the actions of the settlement units of the consolidated subdivision in the elimination of the consequences of an emergency in the border detachment is considered as separable and replaced by the corresponding linearized. Conclusions. The task of determining the optimal composition of forces and means of processing the service of radiation, chemical and biological protection and environmental safety of the State Border Guard Service of Ukraine can be reduced to the classic distribution problem of linear programming of the transport type. In order to organize comprehensive support for the actions of settlement units, it is necessary to fulfill the condition of staffing and equipping units corresponds to the closed distribution task of linear programming of the transport type.

Keywords: emergency response, mathematical programming, composition of forces and means of processing the service of radiation, chemical and biological protection and environmental safety of the State Border Guard Service of Ukraine. 